ANALYTICAL SCIENCE

4 \& TECHNOLOGY

Vol. 26, No. 4, 221-227, 2013

http://dx.doi.org/10.5806/AST.2013.26.4.221

\title{
Validation of LC-MS/MS method for determination of ginsenoside Rg1 in human plasma
}

\author{
Yunjeong Kim ${ }^{1,2, \dagger}$, Song-Hee Han ${ }^{1,2, \dagger}$, Ji-Young Jeon ${ }^{1,2}$, Min-Ho Hwang ${ }^{1,2}$, Yong-Jin Im $^{1,2}$, \\ Sun Young Lee ${ }^{1,3}$, Soo-Wan Chae ${ }^{1,2,4, \star}$ and Min-Gul Kim ${ }^{1,2, \star}$ \\ ${ }^{1}$ Biomedical Research Institute of Chonbuk National University Hospital Chonbuk 561-712, Korea \\ ${ }^{2}$ Clinical Trial Center, Chonbuk National University Hospital Chonbuk 561-712, Korea \\ ${ }^{3}$ Department of Radiation Oncology, Chonbuk National University Hospital Chonbuk 561-712, Korea \\ ${ }^{4}$ Department of Pharmacology, Chonbuk National University Medical School, Chonbuk 561-180, Korea
}

(Received March 6, 2013; Revised June 28, 2013; Accepted July 10, 2013)

\section{인체 혈장 중 Ginsenoside Rg1의 정량을 위한 $\mathrm{LC}-\mathrm{MS} / \mathrm{MS}$ 분석법 검증

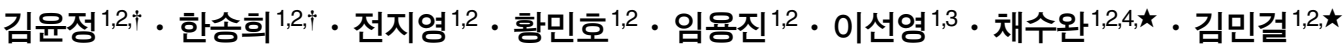 \\ ${ }^{1}$ 전북대학교병원 의생명연구원, ${ }^{2}$ 전북대학교병원 임상시험센터, \\ ${ }^{3}$ 전북대학교병원 방사선종양학과, ${ }^{4}$ 전북대학교 의학전문대학원 약리학교실
}

(2013. 3. 6. 접수, 2013. 6. 28. 수정, 2013. 6. 10. 승인)

\begin{abstract}
A sensitive and selective liquid chromatography-tandem mass spectrometry (LC-MS/MS) was developed for the investigation of the ginsenoside Rg1 in human plasma. After addition of internal standard (digoxin), plasma was diluted with acetone and methanol (80:20), the supernatant was concentrated and analyzed by LC-MS/MS. The optimal chromatographic separation was achieved on an Agilent Eclipse XDB-C18 column $(4.6 \times 150 \mathrm{~mm}, 5 \mu \mathrm{m})$ with a mobile phase of $0.1 \%$ formic acid in water and $0.1 \%$ formic acid in methanol at a flow rate of $0.9 \mathrm{~mL} / \mathrm{min}$ gradient mode. The standard calibration curve for ginsenoside $\mathrm{Rg} 1$ was linear $\left(r^{2}=0.9995\right)$ over the concentration range $1 \sim 500 \mathrm{ng} / \mathrm{mL}$ in human plasma. The intra- and inter-day precision over the concentration range of ginsenoside Rg1 was lower than $7.53 \%$ (correlation of variance, CV), and accuracy exceeded $98.28 \%$. This LC-MS/MS assay of ginsenoside Rg1 in human plasma is applicable for quantifying in the pharmacokinetic study.
\end{abstract}

요 약: LC-MS/MS를 이용하여 인체 혈장 중 ginsenoside Rg1의 신속하고 정확한 분석법을 개발하고 이 분석법에 대한 검증을 수행하였다. 혈장 분석을 위하여 internal standard인 digoxin을 첨가한 후 acetone 과 methanol용액 (80:20)으로 전처리하고, 그 상층액을 진공농축 한 후, LC-MS/MS로 분석하였다. 최적 크로마토그래피 분석은 $0.1 \%$ formic acid 첨가된 water와 methanol을 이동상으로 하여 Agilent Eclipse XDB-C18 column $(4.6 \times 150 \mathrm{~mm}, 5 \mu \mathrm{m})$ 을 이용하여 $0.9 \mathrm{~mL} / \mathrm{min}$ 의 유속으로 gradient mode로 수행하였

\footnotetext{
${ }^{\dagger}$ These authors contributed equally to this work.

$\star$ Corresponding author

Phone : +82-(0)63-250-2236, +82-(0)63-250-2348 Fax : +82-(0)63-250-2349

E-mail : mgkim@jbctc.org, swchae@jbctc.org
} 
다. 혈장 중 ginsenoside $\mathrm{Rg} 1$ 의 표준 검량선은 $1 \sim 500 \mathrm{ng} / \mathrm{mL}$ 의 농도 범위에서 우수한 직선성 $\left(r^{2}=0.9995\right)$ 을 보였으며, 일내, 일간 정밀성은 변동계수 $7.53 \%$ 이하, 정확성은 $98.28 \%$ 이상이었다. 결과적으로 본 분 석법은 ginsenoside $\mathrm{Rg} 1$ 의 약동학 연구에 적용되기에 충분한 감도와 특이성, 직선성, 정밀성 및 정확성을 가지고 있음을 확인하였다.

Key words: ginsenoside Rg1, LC-MS/MS, validation, human plasma

\section{1. 서 론}

인삼 (Panax Ginseng C. A. Meyer)은 오갈피나무과 (Araliaceae)에 속하는 다년생 초본이다. 인삼은 약 2,000 년 동안 한국, 중국, 일본과 같은 동아시아지역 에서 전통의약품으로 사용되어왔고 최근에는 전세계 적으로 주목 받고 있다. ${ }^{1}$ 인삼에는 다양한 성분들이 존재하는데 그 중에서 주요한 활성성분은 ginsenoside 로서 triterpenoid dammarane의 유도체이다. 현재까지 자연상태나 가공상태의 고려인삼에서 분리된 ginsenoside는 31종류 이상이고, 새로운 ginsenoside에 대해서 는 계속 연구되고 있다. ${ }^{2}$ 이러한 ginsenoside의 약리적 활성으로는 항암효과, ${ }^{3}$ 항당뇨효과, ${ }^{4}$ 중추신경계 질환 의 예방, ${ }^{5}$ 항고혈압효과, ${ }^{6-7}$ 항피로와 항스트레스, ${ }^{8-9}$ 항 염증효과 ${ }^{10}$ 등이 있다. Ginsenoside는 배당체의 화학구 조에 따라 protopanaxadiol그룹, protopanaxatriol그룹 및 oleanane그룹으로 분류한다. 이중에서 대부분이 diol그 룹와 triol그룹이고, oleanane그룹은 Ro하나로, 전체 ginsenoside의 $0.6 \%$ 정도에 불과하다. ${ }^{11}$ Diol그룹의 ginsenoside $\mathrm{Rb} 1, \mathrm{Rb} 2, \mathrm{Rc}$ 와 $\mathrm{Rd}$, triol그룹의 $\mathrm{Rg} 1$ 과 $\mathrm{Re}$ 는 인삼에서 비교적 높은 함량으로 존재하는 것으로 알려져 있고, 이중 ginsenoside Rb1과 Rg1은 국내의 건강기능식품, $\mathrm{KS}$ 및 Codex 국제 규격에서 인삼의 주요 지표성분으로 활용되고 있다. ${ }^{12-13}$

Ginsenoside를 분석하기 위한 기존의 방법들은 정 성분석이 가능한 TLC(thin layer chromatography)법, ${ }^{14}$ TMS 유도체화를 이용한 기체-액체 크로마토그래피 (gas-liquid chromatography)법, ${ }^{15}$ 고성능액체크로마토 그래피(high performance liquid chromatography, HPLC) 법 ${ }^{16-17}$ 등이 있다. Jeong 등은 역상 고속 액체크로마토 그래피 (reverse-phase high performance liquid chromatography)를 이용하여 UV detector $203 \mathrm{~nm}$ 에서 ginsenoside $\mathrm{Rg} 2$ 와 $\mathrm{Rg} 3$ 이성질체를 분리하였고, ginsenoside $\mathrm{Rb} 1$, $\mathrm{Rb} 2, \mathrm{Rc}, \mathrm{Rd}, \mathrm{Re}, \mathrm{Rf}$ 그리고 $\mathrm{Rg} 1$ 을 50 분 이내에 분리 하였다. ${ }^{18-19}$ 그러나 이러한 분석법은 인삼 내의 다양한 ginsenoside를 정성, 정량 분석하기에 미량 성분들의
낮은 감도와 분리능에 한계가 있다. HPLC 분석법은 ginsenoside들의 동시분석이 가능한 반면 건강기능식 품 기준 및 규격에 기재된 방법의 경우만하더라도 ginsenoside $\mathrm{Rb} 1$ 과 $\mathrm{Rg} 1$ 의 분석시간이 80 분 가량으로 매우 길다 ${ }^{12}$. 현재 다양한 전처리 방법과 컬럼, 검출기 를 사용하여 효율적인 분석법 개발을 위한 연구가 지 속되고 있고, 최근에는 액체 크로마토그래피-질량분석 기(liquid chromatography-tandem mass chromatography, $\mathrm{LC}-\mathrm{MS} / \mathrm{MS}$ )를 이용한 분석법들도 개발되고 있다. ${ }^{20}$ 또한, 기존의 인삼제품 내에 존재하는 ginsenoside에 대한 분석법은 많이 알려져 있으나 인삼 섭취 후 혈 중에 존재하는 ginsenoside의 약동학적 연구를 통한 과학적인 메커니즘 규명은 아직 부족한 실정이다.

본 연구에서는 인삼에 비교적 높은 함량으로 존재 하고, 제품의 기준 규격 설정 시 지표성분으로 활용되 는 ginsenoside $\operatorname{Rg} 1$ 에 대한 혈중 농도 분석법을 개발 하고자 하였다. 혈중 농도 분석에 있어 $\operatorname{Sun}$ 등 $^{21}$ 은 고 체상 추출법(solid phase extraction, SPE)으로 전처리 하여 LC-MS를 이용한 rat의 혈장에서 ginsenoside $\operatorname{Rg} 1$ 분석법을 제시하였고, Song 등 22 은 $\operatorname{dog}$ 에서의 분 석법을 제시하였다. Liu 등 23 은 인체 혈장과 뇨시료를 $\mathrm{SPE}$ 로 전처리하여 ginsenoside $\mathrm{Re}, \mathrm{Rg} 1, \mathrm{Rg} 2, \mathrm{~F} 1$ 및 $\mathrm{Rh} 1$ 을 동시 분석하였으나 SPE 추출법은 분석자의 숙 련도에 따라 재현성이 달라질 수 있고, 비용이 많이 들며, 재단백전처리법이나 액체-액체 추출법보다 시간 이 오래 걸리는 단점이 있다.

따라서, 본 연구팀은 LC-MS/MS를 이용하여 인체 혈장에서 ginsenoside $\mathrm{Rg} 1$ 의 빠르고 정확한 분석법을 개발하고, 개발된 분석법의 유효성을 밸리데이션 과정 을 통하여 과학적으로 검증하고자하였다.

\section{2. 실험방법}

\section{1. 시약 및 기기}

본 연구에서 사용한 표준물질인 ginsenoside Rg1은 앰보연구소 (purity 98\%) (Seoul, Korea)에서 구입하였 


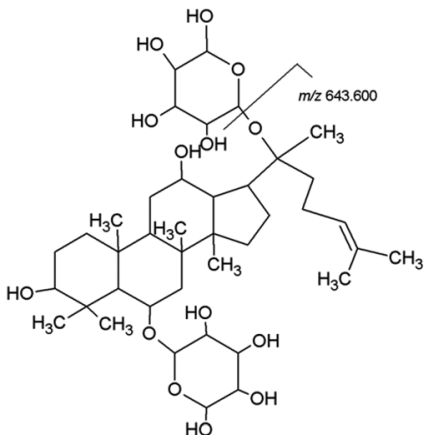

A

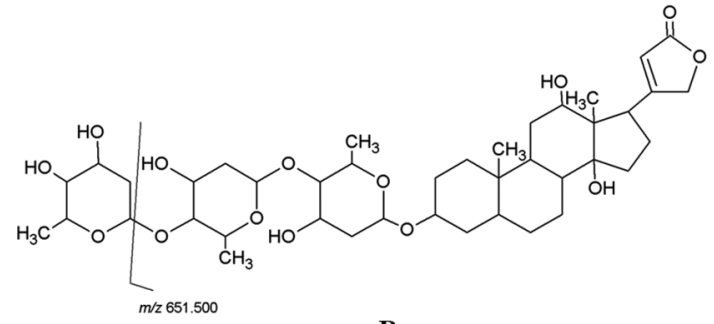

B

Fig. 1. Chemical structure of ginsenoside $\operatorname{Rg} 1$ (A), $(\mathrm{m} / \mathrm{z}$ $823.600643 .600)$ and internal standard (B), (m/z $781.453651 .500)$

고, internal standard로 사용한 digoxin 표준품은 Sigma Chemical Co. (St. Louis, Mo, USA) 로부터 구입하였 다(Fig. 1). 공혈장은 헌혈에 의한 전혈 채혈 후 8시간 이내에 냉장 원심분리기(1차, $2700 \mathrm{rpm}, 2$ 차, 4000 $\mathrm{rpm})$ 를 사용하여 분리된 혈장으로 급속동결하여 $-20{ }^{\circ} \mathrm{C}$ 이하에 보관된 것으로 대한적십자사 전북혈액원을 통 하여 공급받아 사용하였다. 이동상으로 사용한 acetone 은 Wako pure chemical (Osaka, Japan) 제품을 사용하 였고, methanol은 Fisher Scientific Co. (Pittsburgh, PA, USA) 제품을 사용하였다. 또한, HPLC 등급의 water 와 acetonitrile도 Fisher 제품을 사용하였다. 약물분석 기기로는 Agilent HPLC 1200 series (Agilent Technologies, Palo Alto, CA, USA), API4000 LC-MS/MS (AB $\mathrm{SCIEX}$, Foster City, CA, USA)와 원심분리기 (MICRO 17TR, Hanil Science Industrial Co, Korea) 등을 사용 하였다.

\subsection{LC-MS/MS 조건 최적화}

혈장 중 ginsenoside $\mathrm{Rg} 1$ 정량을 위하여 질량분석기 의 전기분무이온화법 (electrospray ionization (ESI) mode)을 사용하였으며, $50 \mathrm{~V}$ 의 collision energy (CE) 로 분석하였다. Ginsenoside Rg1의 precursor molecular ion과 product ion의 $m / z$ 는 각각 823.600과 643.600으
로 모니터링하였고, digoxin의 precursor ion의 $m / z$ 는 781.453으로, product ion의 $m / z$ 는 651.500으로 모니터 링하였다. 또한, 이동상은 $0.1 \%$ formic acid가 첨가된 water $(\mathrm{A})$ 와 $0.1 \%$ formic acid가 첨가된 methanol $(\mathrm{B})$ 로 0 분: $50 \%(\mathrm{~A}) 50 \%(\mathrm{~B}), 1$ 분: $0 \%$ (A) $100 \%(\mathrm{~B})$, 4.5 분: $0 \%(\mathrm{~A}) 100 \%(\mathrm{~B}), 4.6$ 분: $50 \%$ (A) $50 \%$ (B), 6.5 분: $50 \%(\mathrm{~A}) 50 \%(\mathrm{~B})$ 와 같이 기울기 용리 조건으 로 설정하였다. 컬럼은 Eclipse XDB-C18 컬럼 $(4.6 \times$ $150 \mathrm{~mm}, 5 \mu \mathrm{m}$, Agilent Technologies, USA)을 사용하 였고, 유속은 $0.9 \mathrm{~mL} / \mathrm{min}$, 주입량은 $10 \mu \mathrm{L}$ 로 하여 분 석하였다.

\section{3. 표준검량선 작성 및 분석법 검증}

Ginsenoside $\mathrm{Rg} 1$ 및 digoxin 표준품을 methanol에 녹여 각각 $1 \mathrm{mg} / \mathrm{mL}$ 로 만들었다. Ginsenoside $\mathrm{Rg} 1$ 은 $10,20,100,500,1000,2000,4000,5000 \mathrm{ng} / \mathrm{mL}$ 의 농 도로 만들어 공혈장 $80 \mu \mathrm{L}$ 에 digoxin $10 \mu \mathrm{L}(10 \mu \mathrm{g} /$ $\mathrm{mL}$ )를 넣고 만들어 놓은 표준시료 각 $10 \mu \mathrm{L}$ 를 넣어 최종 농도 $1,2,10,50,100,200,400,500 \mathrm{ng} / \mathrm{mL}$ 농 도로 만든 후 acetone과 methanol 용액 (80:20)을 500 $\mu \mathrm{L}$ 더하여 넣고 3 분간 혼합하였다. 그 후 $4{ }^{\circ} \mathrm{C}$ 로 설 정해 둔 원심분리기를 사용하여 $15,000 \mathrm{~g}$ 에서 10 분 동안 원심분리하였다. 원심분리 후 상등액 $300 \mu \mathrm{L}$ 를 진 공원심농축기 (Eppendorf AG, 2231, hamburg, Germany) 에서 $45{ }^{\circ} \mathrm{C}, 45$ 분간 진공농축하였다. 진공농축 후 잔 사액에 $50 \%$ methanol $100 \mu \mathrm{L}$ 를 더하여 넣은 후 1 분 간 혼합한 후, $4{ }^{\circ} \mathrm{C}, 15,000 \mathrm{~g}$ 에서 10 분 동안 원심분 리하였다. LC-MS/MS vial에 옮겨 분석하였으며 2, $200,400 \mathrm{ng} / \mathrm{mL}$ 농도의 품질관리(quality control, QC) 시료 또한 혈장시료를 이용하여 상기의 검체 처리방 법으로 처리하여 분석하였다. 표준 검량선용 용액의 LC-MS/MS 분석 결과에서 얻은 internal standard인 digoxin의 peak 면적에 대한 ginsenoside Rg1의 peak 면적비를 구하여 검량선을 작성하였다.

분석법 검증을 위한 특이성 시험으로서 6 개의 다른 기원의 공혈장을 준비하여 각 시료에 정량한계(limit of quantitation, LOQ)농도의 ginsenoside $\mathrm{Rg} 1$ 을 spiking하 여 분석 시 다른 물질들에 의한 간섭이 없는지 확인하 였다. 직선성 실험을 위해서는 얻어진 크로마토그램으 로부터 internal standard의 peak 면적에 대한 ginsenoside $\mathrm{Rg} 1$ 의 peak 면적비를 구하고, 검량선은 선형회귀 방 법으로 구하였으며 가중치는 $1 / \mathrm{x}$ 을 이용하였다. QC시 료로는 2, 200, $400 \mathrm{ng} / \mathrm{mL}$ 농도의 혈장 표준시료를 이용하여 상기의 검체 처리방법으로 처리하여 분석하 
였다 $(n=5)$. 정밀성은 각 성분과 internal standard의 측 정치의 표준편차를 평균값으로 나눈 비의 백분율 $(\%)$ 로서 구하였다. 하루에 5 번 시행하여 일내 정밀성 $(\%$, 상관계수(correlation of variance, $\mathrm{CV}$ )로 표시)을 구하 였고 5 일간 실험을 반복 시행하여 일간 정밀성을 구 하였다. 회수율은 검량선에 의하여 정량한 농도의 평 균값을 기지의 농도로 나눈 비의 백분율 $(\%)$ 로서 구하 였다. 시험방법의 회수율을 조사하기 위하여 ginsenoside $\operatorname{Rg} 1$ 이 포함된 혈장시료를 우선 전처리 한 후, internal standard를 가하여 각 성분의 회수율을 구하였고, internal standard도 동일한 방법으로 혈장에 첨가하여 우선 전 처리한 다음 농도를 알고 있는 표준물질용액을 가하 여 분석하고 얻어진 크로마토그램의 peak 면적비를 이용하여 회수율을 구하였다.

\section{3. 결과 및 고찰}

\section{1. 특이성}

건강한 성인의 공혈장에 internal standard만 spiking 한 것과 ginsenoside $\operatorname{Rg} 1$ 을 함께 spiking한 것에 대해 본 시험 방법에 따라 LC-MS/MS로 분석하였다. Fig. 2 는 ginsenoside $\operatorname{Rg} 1$ 만 따로 넣었을 때 그리고 혼합했 을 때 각각의 LC-MS/MS 크로마토그램을 나타낸 것 이다. Ginsenoside Rg1과 digoxin의 머무름 시간은 각 각 3.25 분과 3.33 분이었고, ginsenoside $\mathrm{Rg} 1$ 의 질량을 두 물질의 질량 사이의 차로 나누는 질량분석계의 분 리능(resolution)을 계산하였을 때, 70.067 이었다. 두 성분에 대한 peak의 골짜리 높이와 봉우리 높이의 분 율은 $6.7 \%$ 로 $10 \%$ 를 넘지 않아 두 성분은 잘 분리되

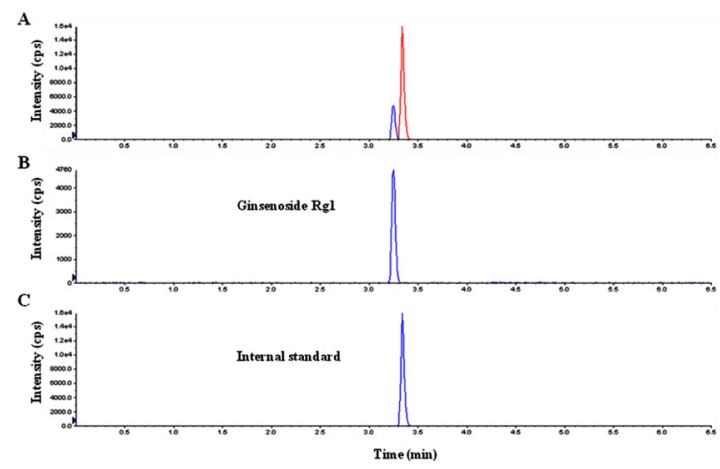

Fig. 2. Chromatograms of human plasma spiked with (A) ginsenoside $\operatorname{Rg} 1(10 \mathrm{ng} / \mathrm{m})$ and digoxin $(10 \mu \mathrm{g} / \mathrm{mL})$, (B) ginsenoside $\mathrm{Rg} 1$ (10 ng/mL), and (C) digoxin (10 $\mu \mathrm{g} / \mathrm{mL})$.
었다. Internal standard를 가하지 않은 공혈장에서는 크로마토그램상에 peak가 검출되지 않았으며, internal standard를 첨가한 공혈장에서는 internal standard의 peak만 검출되었고, internal standard가 ginsenoside $\mathrm{Rg} 1$ 의 크로마토그램에 영향을 주지 않음을 확인하였 다. 본 실험의 분석 조건에서 ginsenoside $\mathrm{Rg} 1$ 및 internal standard는 기타 혈장에 존재하는 다른 성분들과 잘 분리되었다. 여섯 개의 다른 기원을 가진 공혈장에 최 저정량한계 농도를 spiking하여 분석하였을 때, 각 성 분의 peak가 다른 간섭효과 없이 잘 분석되는 것을 확인하였다.

\section{2. 직선성}

표준물질 $1,2,10,50,100,200,400,500 \mathrm{ng} / \mathrm{mL}$ 의 혈장시료에 internal standard를 spiking한 혈장시료를 전처리하여 $\mathrm{LC}-\mathrm{MS} / \mathrm{MS}$ 로 분석하여 $r^{2}$ 을 구한 결과 0.9995 로 양호한 직선성을 나타내었고, 검출한계(limit of detection, LOD)는 신호 대 잡음비(signal to noise ratio, $\mathrm{s} / \mathrm{n}$ ratio)가 3 대 1 일 때의 농도, $\mathrm{LOQ}$ 는 $\mathrm{s} / \mathrm{n}$ ratio 가 10 대 1 일 때의 농도로 구한 결과 각각 $0.4,1 \mathrm{ng} /$ $\mathrm{mL}$ 이었다. 혈장 시료로부터 구한 ginsenoside $\mathrm{Rg} 1$ 의 계산식은 $\mathrm{y}=0.028 \mathrm{x}-0.00769 \quad\left(r^{2}=0.9995\right) \quad[\mathrm{y}=$ ginsenoside $\mathrm{Rg} 1 /$ internal standard의 peak 면적의 비율, $\mathrm{x}=$ ginsenoside $\operatorname{Rg} 1$ 의 농도 $(\mathrm{ng} / \mathrm{mL})$ ]였으며 $1 \sim 500 \mathrm{ng} / \mathrm{mL}$ 의 범위 에서 양호한 직선성을 나타내었다(Fig. 3).

\section{3. 정확성 및 정밀성}

정밀성은 ginsenoside $\mathrm{Rg} 1$ 과 internal standard의 peak 면적비의 표준편차를 ginsenoside $\operatorname{Rg} 1$ 과 internal standard의 peak 면적비의 평균값으로 나눈 비의 백분 율 $(\%)$ 로서 구하였다. 표준용액에 대하여 $\mathrm{QC}$ 시료는 2, $200,400 \mathrm{ng} / \mathrm{mL}$ 로 하루에 5 번 시행하여 일내 정밀성 을 구하였고, 5 일간 실험을 반복 시행하여 일간 정밀 성을 구하였다. 또한, 정확성은 검량선에 의하여 정량

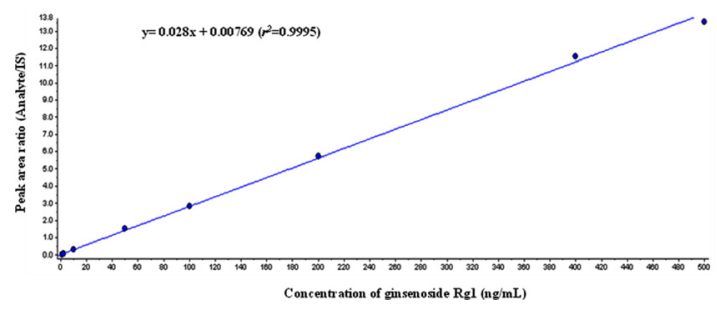

Fig. 3. Standard calibration curve of ginsenoside $\operatorname{Rg} 1$ in human plasma. 
Table 1. Intra- and inter-day precision and accuracy $(\mathrm{n}=5)$ of ginsenoside Rg1 QC samples in human plasma

\begin{tabular}{lrrr}
\hline \hline \multirow{2}{*}{ Parameter } & \multicolumn{3}{c}{ Concentration $(\mathrm{ng} / \mathrm{mL})$} \\
\cline { 2 - 4 } & 2.00 & 200.00 & 400.00 \\
\hline Intra-day $^{\mathrm{a})}$ & & & \\
Mean & 2.05 & 204.50 & 398.00 \\
CV $(\%)^{\mathrm{c})}$ & 7.53 & 4.64 & 4.89 \\
RE $(\%)^{\mathrm{d})}$ & 2.25 & 2.25 & -0.50 \\
Accuracy $(\%)$ & 102.18 & 102.47 & 99.55 \\
\hline Inter-day) & & & \\
Mean & 1.97 & 209.80 & 408.60 \\
CV (\% & 6.22 & 2.51 & 3.98 \\
RE (\%) & -1.70 & 4.90 & 2.15 \\
Accuracy(\%) & 98.28 & 105.20 & 102.16 \\
\hline
\end{tabular}

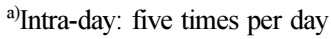

b)Inter-day: one time analysis of ginsenoside $\mathrm{Rg} 1$ per day for 5 days

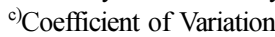

d) Relative Error

Table 2. Recovery of ginsenoside $\mathrm{Rg} 1$ in human blank plasma QC samples at intra- and inter-day $(n=5)$

\begin{tabular}{ccc}
\hline \hline \multirow{2}{*}{$\begin{array}{c}\text { Concentration } \\
(\mathrm{ng} / \mathrm{mL})\end{array}$} & \multicolumn{2}{c}{ Recovery(\%, Mean \pm S.D $)$} \\
\cline { 2 - 3 } & Intra-day & Inter-day \\
\hline 2 & $102.25 \pm 0.15$ & $98.30 \pm 0.12$ \\
200 & $102.25 \pm 9.47$ & $104.90 \pm 5.26$ \\
400 & $99.50 \pm 19.46$ & $102.15 \pm 16.28$ \\
\hline
\end{tabular}

한 농도의 평균값을 기지의 농도로 나눈 비의 백분율 (\%)로서 구하였다. 감도(정량한계)는 크로마토그램 상 에서 $\mathrm{s} / \mathrm{n}$ ratio를 10 이상으로 하였다. 판정기준은 $\mathrm{CV}(\%)$ 가 $10 \%$ 이하를 만족하는 지와 정확성(Accuracy, \%)
$85 ~ 115 \%$ 일 때 만족하는 것으로 판정하였으며, 실험 결과 Table 1 에 나타난 것처럼 일내 분석시의 $\mathrm{CV}(\%)$ 는 4.64 7.53\%로 만족하는 결과를 보였고, 일간 분석 시의 $\mathrm{CV}(\%)$ 2.51 6.22\%의 결과를 나타내었다. 혈장 시료의 정확성은 모두 기준을 만족하였다. 추출효율의 실험결과는 회수율로서 평가하였으며, 기지 량의 분석 물질에 대해 본 시험법의 시료 추출과 처리과정을 모 두 거친 후 얻은 분석치의 기지 량에 대한 퍼센트로 계산하여 $85 \sim 115 \%$ 일 경우 적합으로 판정하였고, 일 내, 일간 실험결과 98.90-104.90\%로 적합한 결과를 나 타내었다(Table 2).

이때 본 분석방법의 정밀성은 일내, 일간 모두 $10 \%$ 이하, $\mathrm{LOQ}$ 에서의 정밀성은 $20 \%$ 이하였고, $\mathrm{LOQ}$ 는 1 $\mathrm{ng} / \mathrm{mL}$ 이었다. 이로부터 혈중 ginsenoside $\mathrm{Rg} 1$ 에 대한 상기 LC-MS/MS 분석법은 인체에 대한 생체이용률시 험 및 약물상호작용 연구 등 약동학적 특성을 평가하 는 임상연구에 이용될 수 있는 충분한 감도, 특이성, 직 선성, 정확성 및 정밀성을 갖고 있음을 알 수 있었다.

본 연구팀은 추가적으로 임상시험에서 인삼제품을 복용한 후 혈중 ginsenoside $\operatorname{Rg} 1$ 분석시에 다른 ginsenoside peak의 방해를 받지 않고 분리가 잘 되는 지 확인시험을 실시하였다. 공혈장에 ginsenoside $\mathrm{Rg} 1$, ginsenoside $\mathrm{Rb} 1$, ginsenoside $\mathrm{Rc}$, ginsenoside $\mathrm{Rh} 2$, 그 리고compound $\mathrm{K}$ 표준품을 spiking하여 각각 $500 \mathrm{ng} /$ $\mathrm{mL}$ 로 조제하여 internal standard와 분석하였고, 6 개의 ginsenoside 표준품을 혼합하여 동시분석하였다. 그 결 과 ginsenoside $\mathrm{Rg} 1$, ginsenoside $\mathrm{Rb} 1$ 과 internal standard 의 peak을 확인 할 수 있었다(Fig. 4). 이 결과는 각각 을 분석했을 때와 같은 결과로 ginsenoside Rc, Rh2와

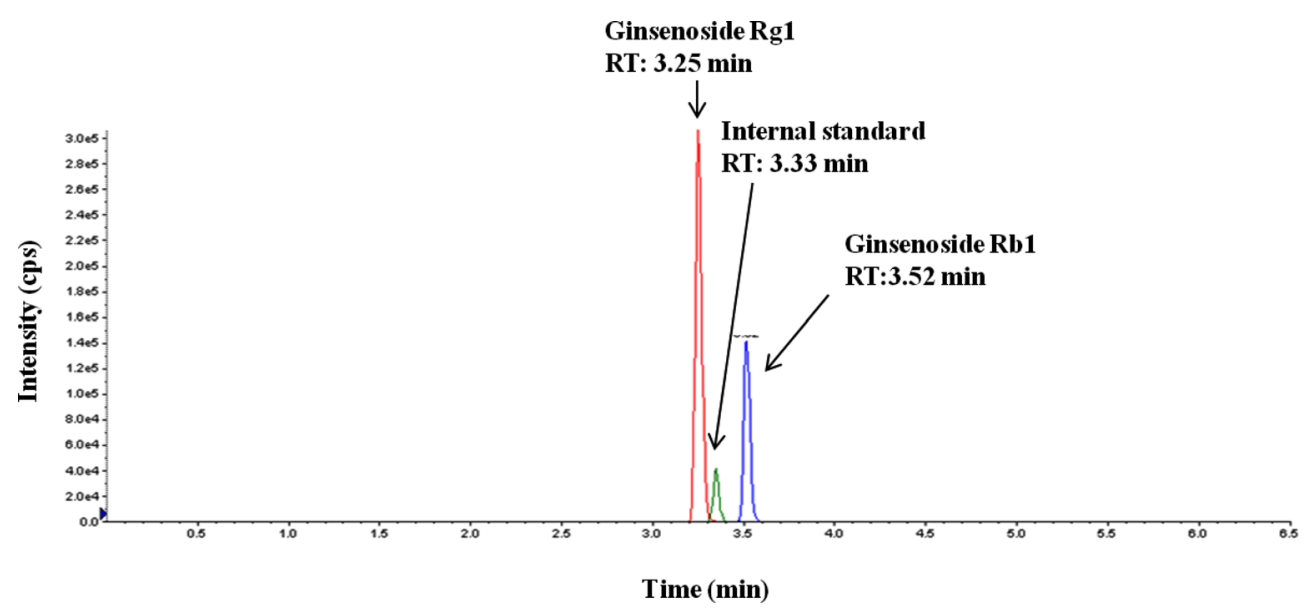

Fig. 4. Chromatograms for mixture of ginsenoside $\mathrm{Rg} 1, \mathrm{Rb} 1, \mathrm{Rc}, \mathrm{Rh} 2$, compound $\mathrm{K}$ and internal standard in human plasma 
compound $\mathrm{K}$ 의 peak는 검출되지 않았고, 검출된 ginsenoside Rb1과 internal standard의 peak도 머무름 시간이 달라 ginsenoside $\operatorname{Rg} 1$ 의 peak에 영향을 주지 않았다.

기존의 Ginsenoside의 약동학 연구는 rat에 ginsenoside 등을 주사하거나 경구투여해서 비교해보거나 $\operatorname{dog}$ 에게 경구투여하여 혈중 농도를 측정하는 전임상연구들이 많이 있으나, Rat나 $\operatorname{dog}$ 의 혈장은 인체혈장은 성분이 달라서 matrx effect가 다르기 때문에 인체혈장에서의 분석법을 확립하는 것이 중요하다. $22,24-25$

Liu 등은 피험자에게 ginsenoside Re를 경구투여하 여 혈장과 뇨에서 ginsenoside $\mathrm{Re}, \mathrm{Rg} 1, \mathrm{Rg} 2, \mathrm{~F} 1, \mathrm{Rh} 1$, protopanaxatriol을 동시 분석하였으나 ginsenoside $\operatorname{Rg} 1$ 의 최저정량한계(low limit of quantitation, LLOQ)는 $0.5 \mathrm{ng} / \mathrm{mL}$ 로 낮은데 반해 $r^{2}$ 이 0.9981 로, 본 연구 결 과값인 0.9995 의 직선성이 더 우수하였다. ${ }^{23}$ 또한 $\mathrm{SPE}$ 를 이용한 전처리방법은 추출하는데 오랜 시간이 소 요되고, 많은 양의 시료 사용과 cartridge 사용에 따른 비용 문제가 있다. ${ }^{23}$ 따라서 본 분석법은 기존의 분석 법보다 간단하고, 빠르고 정확하게 ginsenoside $\operatorname{Rg} 1$ 을 정량할 수 있는 분석법이다. 본 연구를 바탕으로 다른 ginsenoside들의 동시분석법이 확립된다면 인삼제품 섭취 후 혈중 ginsenoside 농도 측정을 통해 metabolic pathway 연구에 많은 정보를 줄 수 있을 것으로 기대 된다.

\section{4. 결 론}

Ginsenoside $\mathrm{Rg} 1$ 의 인체 혈장 중의 LC-MS/MS 분 석법을 설정하고 이 분석법의 유효성을 검증하는 실 험을 하여 다음과 같은 결론을 얻었다. 혈장시료를 전 처리하여 LC-MS/MS 크로마토그램으로 분석한 결과 혈장성분 내부에 있는 여러 가지 간섭물질의 방해 없 이 ginsenoside $\operatorname{Rg} 1$ 및 internal standard가 분리되었다. 혈장시료로부터 구한 ginsenoside $\operatorname{Rg} 1$ 의 검량선은 $r^{2}$ $\geq 0.999$ 로 $1-500 \mathrm{ng} / \mathrm{mL}$ 범위에서 양호한 직선성을 나 타내었고 $\mathrm{LOQ}$ 는 $1 \mathrm{ng} / \mathrm{mL}$ 이었다. 분석법을 검증한 결 과 일내 재현성과 일간 재현성의 평균 정밀성과 정확 성이 모두 기준값 이내에 들어 이 분석법은 충분한 감도와 정확성 및 정밀성이 있었다. 이 분석법은 이미 보고된 분석법에 비교하여 시료 전처리가 간단하고, 낮은 정량한계를 가지며, 생체시료 분석법으로서의 양 호한 특이성, 직선성, 정확성 및 정밀성을 나타내었다. 따라서 $\mathrm{LC}-\mathrm{MS} / \mathrm{MS}$ 분석법을 이용한 인체 혈장 내의 ginsenoside $\operatorname{Rg} 1$ 을 정량한 본 시험법은 적합한 시험법 임을 검증하였다. 향후 본 연구에서 정립한 ginsenoside $\operatorname{Rg} 1$ 의 생체시료분석법을 약동학 연구에 연구에 적용 할 수 있을 것으로 예상되고, 본 분석법은 추후 다른 protopanaxatriol 그룹의 ginsenoside들의 생체시료 내 분석법 확립과 더불어 인삼의 체내 약동학적 메카니 즘에 대해 규명에 기반이 될 것이다.

\section{참고문헌}

1. J. T. Baker, R. P. Borris, B. Carté, G. A. Cordell, D. D. Soejarto, G. M. Cragg, M. P. Gupta, M. M. Iwu, D. R. Madulid and V. E. Tyler, J. Nat. Prod., 58(9), 13251357 (1995).

2. C. S. Yuan, C. Z. Wang, S. M. Wicks and L. W. Qi, J. Ginseng Res., 34(3), 160-167 (2010).

3. M. Mochizuki, Y. C. Yoo, K. Matsuzawa, K. Sato, I. Saiki, S. Tono-oka, K. Samukawa and I. Azuma, Biol. Pharm. Bull., 18(9), 1197-1202 (1995).

4. T. Yokozawa, T. Kobayashi, H. Oura, and Y. Kawashima, Chem. Pharm. Bull., 33(2), 869-872 (1985).

5. K. Takagi, H. Saito and H. Nabata, Jpn. J. Pharmacol., 22(2), 245-249 (1972).

6. P. M. Stavro, M. Woo, T. F. Heim, L. A. Leiter and V. Vuksan, Hypertension, 46(2), 406-411 (2005).

7. C. Pan, Y. Huo, X. An, G. Singh, M. Chen, Z. Yang, J. $\mathrm{Pu}$ and J. Li, Vascul. Pharmacol., 56(3-4), 150-158 (2012).

8. H. Saito, Y. Yoshida,and K. Takagi, Jpn. J. Pharmacol., 24(1), 119-127 (1974).

9. B. X. Wang, J. C. Cui, A. J. Liu and S. K. Wu, J. Tradit. Chin. Med., 3(2), 89-94 (1983).

10. H. Matsuda, K. Samukawa and M. Kubo, Planta Med., 56(1), 19-23 (1990).

11. P. Hu, G. A. Luo, Q. Wang, Z. Z. Zhao, W. Wang and Z. H. Jiang, Arch. Pharm. Res., 31(10), 1265-1273 (2008).

12. '건강기능식품의 기준 및 규격 전면 개정(식품의약품 안정청고시 제 2008-12호)', 식품의약품안전청.

13. 인삼 및 인삼제품-진세노사이드(Rb1, Rg1)함량 측정 -고속액체크로마토그래프법(KS H 2153)', 산업자원 부 기술표준원.

14. H. Oura, S. Hiai, Y. Odaka and T. Yokozawa, J. Biochem., 77(5), 1057-1065 (1975).

15. O. Sticher and F. Soldati, Planta Med., 36(1), 30-42 
(1979).

16. T. T. Yip, C. N. Lau, P. P. But and Y. C. Kong, Am. J. Chin. Med., 13(1-4), 77-88 (1985).

17. N. Fuzzati, J. Chromatogr. B., 812(1-2), 119-133 (2004).

18. S. I. Jeong, C. S. Kim, Y. G. Lee, H. S. Lee and I. K. Kim, Anal. Sci. Technol., 11(5), 404-407 (1998).

19. S. I. Jeong, C. S. Kim, N. W. Lee, K. J. Choi, Y. G. Lee and I. K. Kim, Anal. Sci. Technol. 11(6), 436-439 (1998).

20. W. Chen, Y. Dang and C. Zhu, Chin. Med., 5, 12 (2010).
21. J. Sun, G. Wang, X. Haitang, L. Hao, P. Guoyu and I. Tucker, J. pharmaceut. Biomed., 38(1), 126-132 (2005).

22. M. Song, S. Zhang, X. Xu, T. Hang and L. Jia, J. Chromatogr. B., 878(32), 3331-3337 (2010).

23. L. Liu, J.Huang, X. Hu, K. Li and C. Sun J. Chromatogr. B., 879(22), 2011-2017 (2011).

24. J. Zhao, C. Su, C. Yang, M. Liu, L. Tang, W. Su, Z. and Liu J. Pharm. Biomed. Anal., 64-65, 94-97 (2012).

25. D. N. Patel, H. S. Lin and H. L. Koh J. Mass Spectrum., 47, 1510-1517 (2012). 